\title{
Association of nonalcoholic fatty liver with carotid intima-media thickness in patients with dyslipidaemia
}

\section{Zależność między niealkoholowym stłuszczeniem wątroby a grubością błony środkowej i wewnętrznej tętnicy szyjnej u pacjentów z dyslipidemią}

\author{
Hamid Dehdashti Shahroukh ${ }^{1}$, Mohammad Davoodi², Obeyid Rahmani ${ }^{1}$, Amin Roushanaei ${ }^{1}$, \\ Seyed Masoud Seydeyan ${ }^{3}$, Seyed Mohammad Hassan Adel $^{3}$ \\ 'Department of Radiology, Atherosclerosis Research Centre, Ahvaz Jundishapur University of Medical Sciences, Ahvaz, Iran \\ Head of the Department: Dr. Mohammad Momen Gharibvand \\ ${ }^{2}$ Department of Radiology, Shariati Hospital, Tehran University of Medical Sciences, Tehran, Iran \\ Head of the Department: Dr. Mohammad Momen Gharibvand \\ ${ }^{3}$ Department of Cardiology, Atherosclerosis Research Centre, Ahvaz Jundishapur University of Medical Sciences, Ahvaz, Iran \\ Head of the Department: Dr. Amanollah Heydari
}

Key words: nonalcoholic fatty liver disease, dyslipidaemia, intima-media thickness, ultrasound.

Słowa kluczowe: niealkoholowa stłuszczeniowa choroba wątroby, dyslipidemia, grubość błony środkowej i wewnętrznej, ultrasonografia.

\begin{abstract}
Introduction: Nonalcoholic fatty liver disease (NAFLD) is the most common chronic liver disease in adults, which is associated with metabolic syndrome.

Aim of the research: To investigate the association of fatty liver with carotid intima-media thickness (CIMT) in patients with dyslipidaemia.

Material and methods: Fifty-two patients with uncomplicated NAFLD were enrolled. Sixty-four sex- and aged-match subjects without NAFLD were considered as controls. An ultrasound was performed in the supine and left lateral positions. In all patients, CIMT was measured by high-resolution real-time B-mode ultrasonography with a 7.5-MHz linear transducer. Data, including CIMT, plasma liver function tests, and other biochemical blood measurements, were collected.

Results: The mean CIMT in cases $(0.66 \mathrm{~mm})$ was significantly greater than the controls $(0.58 \mathrm{~mm})(p=0.003)$. The mean CIMT in patients with fatty liver grade III $(0.71 \mathrm{~mm})$ was significantly more than the patient with fatty liver grade II $(0.65 \mathrm{~mm})$ $(p=0.003)$. Older age, hypertension, diabetes, body mass index, and smoking were associated with increased CIMT.

Conclusions: In patients with NAFLD and dyslipidaemia a significant increase in the CIMT has been observed compared to the control. So, it seems that performing liver ultrasound in patients with dyslipidaemia is reasonable, and in the presence of fatty liver, assessment of carotid atherosclerotic changes is recommended, which may lead to therapeutic intervention. Considering ultrasound as a noninvasive and non-ionising radiation imaging technique, as well as its low cost and availability, may make this method an ideal candidate for a diagnosis.
\end{abstract}

\section{Streszczenie}

Wprowadzenie: Niealkoholowa stłuszczeniowa choroba wątroby (NAFLD) jest najczęstszym przewlekłym schorzeniem wątroby u dorosłych, które wiąże się z zespołem metabolicznym.

Cel pracy: Zbadanie związku między stłuszczeniem wątroby a grubością błony środkowej i wewnętrznej tętnicy szyjnej (CIMT) u pacjentów z dyslipidemią.

Materiał i metody: Do badania włączono 52 pacjentów z niepowikłaną NAFLD. Grupę kontrolną stanowiły 64 osoby różnej płci i w różnym wieku bez NAFLD. Badanie ultrasonograficzne wykonano w pozycji leżącej i bocznej lewej. U wszystkich pacjentów zmierzono CIMT podczas badania ultrasonograficznego w prezentacji B w czasie rzeczywistym o wysokiej rozdzielczości z użyciem przetwornika liniowego 7,5 MHz. Ocenie poddano CIMT, wyniki testów czynnościowych wątroby z osocza i badania biochemiczne krwi.

Wyniki: Średnia wartość CIMT u pacjentów z grupy badanej $(0,66 \mathrm{~mm})$ była znacznie większa niż u pacjentów z grupy kontrolnej $(0,58 \mathrm{~mm})(p=0,003)$. Średnia wartość CIMT u pacjentów ze stłuszczeniem wątroby stopnia III $(0,71 \mathrm{~mm})$ była znacznie większa niż u pacjentów ze stłuszczeniem wątroby stopnia II $(0,65 \mathrm{~mm})(p=0,003)$. Starszy wiek, nadciśnienie, cukrzyca, zwiększony wskaźnik masy ciała i palenie tytoniu były związane ze wzrostem wartości CIMT. 
Wniosek: U pacjentów z NAFLD i dyslipidemia stwierdzono znacznie większe wartości CIMT w porównaniu z grupa kontrolną. Wydaje się, że badanie ultrasonograficzne wątroby u pacjentów z dyslipidemią jest uzasadnione. W przypadku stłuszczenia wątroby zaleca się ocenę zmian miażdżycowych tętnic szyjnych, co może prowadzić do interwencji terapeutycznej. Badanie ultrasonograficzne jako nieinwazyjna i niejonizująca technika obrazowania, a także ze względu na niski koszt i dostępność stanowi idealną metodę diagnostyczną.

\section{Introduction}

About a third of the population of the United States has fatty liver and nonalcoholic fatty liver disease (NAFLD) is the most common cause of chronic liver disease in adults [1].

Nonalcoholic fatty liver disease is a form of liver disease, which mimics alcoholic liver disease from the pathological point of view, but it is seen in non-alcoholic individuals. Most of these patients are presented with metabolic conditions such as insulin resistance, weight gain, obesity, diabetes, and associated dyslipidaemia [2-4]. Epidemiological studies have shown that cardiovascular disease is strongly associated with increased serum levels of liver enzymes $[5,6]$, and NAFLD is the most common cause of abnormal liver enzymes in the clinic [7].

Hepatic steatosis (HS) or fatty liver disease is a type of the metabolic syndrome associated with high risk of cardiovascular diseases, particularly increasing the prevalence of carotid lesions [8-10]. The main features of metabolic syndrome include atherogenic dyslipidaemia, impaired glucose tolerance, hypertension, and central obesity. A potential mechanism for NAFLD, with increased cardiovascular risk, is abnormal lipoprotein metabolism [11].

Although abdominal ultrasound has good sensitivity and specificity in the detection of moderate to severe liver disease, its specificity is reduced when liver fat infiltration is less than 33\%. Fatty liver on ultrasound may have an independent effect on the severity of coronary artery disease and coronary atherosclerosis [12].

Carotid intima-media thickness (CIMT) is a marker of early atherosclerosis and its progression and is known to be a predictor of cardiovascular events and end-organ damage [13]. It was reported that among all known risk factors, cholesterol intake, body mass index, and smoking were significantly associated with increased CIMT, and hypertension is the risk factor for CIMT [14]. The CIMT can be assessed by B-mode ultrasound [15].

\section{Aim of the research}

This study aimed to investigate the association of fatty liver with CIMT in patients with dyslipidaemia.

\section{Material and methods}

\section{Study design and population}

Fifty-two patients with uncomplicated NAFLD from Golestan Hospital during 2017 were enrolled.
Sixty-four sex- and aged-matched subjects without NAFLD were considered as controls. This study was approved by the Ethical Committee of Ahvaz Jundishapur University of Medical Sciences (AJUMS), and all patients signed informed consent prior enrolment.

\section{Inclusion criteria}

Patients with triglyceride levels equal to or greater than $150 \mathrm{mg} / \mathrm{dl}$, LDL levels equal to or greater than $130 \mathrm{mg} / \mathrm{dl}$, and HDL levels equal to or less than $40 \mathrm{mg} / \mathrm{dl}$ (male) or $50 \mathrm{mg} / \mathrm{dl}$ (female) were included. All patients with lipid disorders had confirmed NAFLD.

\section{Exclusion criteria}

Patients with alcohol use disorder more than $20 \mathrm{~g} /$ day, history of drug therapy by corticosteroids, chemotherapies or hormones, history of chronic liver diseases, liver enzyme impairment, history of vascular collagen disease, and history of radiotherapy were excluded.

\section{Methods}

Data including CIMT, plasma liver function tests, and other biochemical blood measurements were collected. Following 12-hour fasting an ultrasound examination of the liver was performed. The ultrasound technique was performed according to Poanta et al.'s method [15]. In brief, an ultrasound was done in the supine and left lateral positions. The presence or absence and grading of fatty infiltration of the liver were recorded. In all patients, CIMT was measured by high-resolution real-time B-mode ultrasonography with a 7.5-MHz linear transducer (Aloka Prosound Alpha 10), performed after $12 \mathrm{~h}$ of fasting. Evaluation of the CIMT was carried out with a slight neck extension in the supine position. The carotid arteries were investigated bilaterally in longitudinal scans. The examination included sections of approximately $2-3 \mathrm{~cm}$ of common carotid artery just below the carotid bulb. The CIMT was defined as the distance between the leading edge of the first echogenic line (lumen-intima interface) and the second echogenic line (media-adventitia interface) of the far wall. A carotid plaque was defined as a focal thickening $\geq 1.2 \mathrm{~mm}$ at the level of the carotid artery. Then, fasting blood sugar (FBS) and blood levels of liver enzymes (consisting of ALT and AST) were measured, and data, including a history of smoking, systolic and diastolic blood pressure, weight, and BMI were collected. 


\section{Statistical analysis}

Data on quantitative characteristics are expressed as the mean \pm standard deviation (SD), and in the case of qualitative characteristics are expressed as percentage values or numbers. Comparisons between groups were made using ANOVA (continuous data) and $\chi^{2}$ test (nominal data). A $p$-value less than 0.05 was considered as statistically significant.

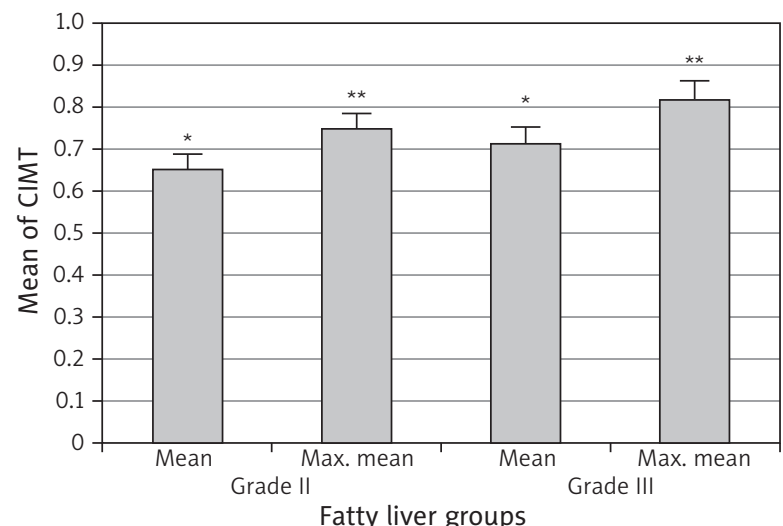

Figure 1. Comparing the mean CIMT between case and control groups $\left({ }^{\star} p=0.003 ;{ }^{* *} p=0.003\right)$

\section{Results}

Overall, 116 patients, including 62 (53.4\%) male and $54(46.6 \%)$ female, were enrolled.

Fifty-two $(44.8 \%)$ patients were considered as cases, and the remaining $64(54.2 \%)$ were the control group. Baseline characteristics of the study groups are presented in Table 1. The mean CIMT in patients with fatty liver grade III was significantly greater than the patients with fatty liver grade II $(0.71 \pm 0.13 \mathrm{~mm}$ vs. $0.65 \pm 0.14 \mathrm{~mm} ; p=0.003$ ) (Figure 1). Moreover, the maximum mean of CIMT in patients with fatty liver grade III was significantly greater than the patients with fatty liver grade II ( $0.82 \pm 0.10$ vs. $0.75 \pm 0.18 \mathrm{~mm}$; $p=0.003$ ) (Figure 1).

Increasing age is associated with increased maximum mean of CIMT, in which for every 10-year increase in the median age in the range of $20-50$ years, there is an increase in the mean and maximum mean of CIMT in patients with dyslipidaemia $(p<0.001$; $\beta=0.11 ; p<0.001 ; \beta=0.15)$, respectively. The CIMT in hypertensive patients with dyslipidaemia was significantly more than in those with normal blood pressure $(p<0.001 ; \beta=0.13)$. Also, the maximum mean of CIMT in hypertensive patients with dyslipidaemia

Table 1. Baseline characteristics of patients with and without dyslipidaemia

\begin{tabular}{|c|c|c|}
\hline Variables & $\begin{array}{l}\text { Patients with dyslipidaemia } \\
52(44.8 \%)\end{array}$ & $\begin{array}{l}\text { Patients without dyslipidaemia } \\
\qquad 64(54.8 \%)\end{array}$ \\
\hline Age (mean \pm SD) [years] & $44.2 \pm 3.5$ & $43.5 \pm 2.9$ \\
\hline $\mathrm{BMI}\left(\right.$ mean $\pm \mathrm{SD}\left[\mathrm{kg} / \mathrm{m}^{2}\right]^{\star}$ & $30.6 \pm 4.7$ & $25.8 \pm 2.9$ \\
\hline \multicolumn{3}{|l|}{ Gender, $n(\%)$ : } \\
\hline Male & $33(63.5)$ & $29(45.3)$ \\
\hline Female & $19(36.5)$ & $35(54.7)$ \\
\hline \multicolumn{3}{|l|}{ Fatty liver grades, $n(\%)$ : } \\
\hline Grade II & $44(84.6)$ & - \\
\hline Grade III & $8(15.4)$ & - \\
\hline \multicolumn{3}{|l|}{ Smoking, $n$ (\%): } \\
\hline Smoker & $8(11.1)$ & $3(4.7)$ \\
\hline Non-smokers & $48(88.9)$ & $61(95.3)$ \\
\hline \multicolumn{3}{|l|}{ Hypertension, $n$ (\%): } \\
\hline Yes & $13(25)$ & $6(9.4)$ \\
\hline No & $39(75)$ & $58(90.6)$ \\
\hline \multicolumn{3}{|l|}{ History of diabetes, $n$ (\%): } \\
\hline Yes & 9 (17.3) & $2(3.1)$ \\
\hline No & $43(82.7)$ & $62(96.9)$ \\
\hline \multicolumn{3}{|l|}{ CIMT [mm]: } \\
\hline Mean & 0.66 & 0.58 \\
\hline Maximum mean & 0.76 & 0.66 \\
\hline
\end{tabular}


was significantly greater than in those with normal blood pressure $(p<0.001 ; \beta=0.2)$. Thus, hypertension in the presence of dyslipidaemia is significantly correlated with fatty liver and increases its chance by 3.23 times $(p=0.029$; OR $=3.23)$.

When diabetes is associated with dyslipidaemia, it significantly increases the risk of fatty liver by 6.49 times ( $p=0.020$; OR $=6.49$ ), and when it is associated with hypertension, it increases the risk of fatty liver by 8.49 times $(p=0.002 ; \mathrm{OR}=8.49)$. In addition, the mean CIMT of diabetic patients with dyslipidaemia, aged 20 to 50 years, was significantly greater than those with normal blood pressure ( $p=0.029 ; \beta=0.10)$. Besides, maximum mean CIMT of diabetic patients with dyslipidaemia, aged 20 to 50 years, was more than those with normal blood pressure ( $p=0.006$; $\beta=0.16$ ).

Each unit increase in BMI increases thce risk of developing diabetes by 1.25 -fold ( $p=0.001$; $\mathrm{OR}=$ 1.25 ) and intermediately affects the CIMT. Moreover $\mathrm{BMI}$ is directly associated with fatty liver, and the risk of fatty liver in people with a BMI equal to or above $25 \mathrm{~kg} / \mathrm{m}^{2}$ is 9.33 times more than in those with a BMI less than $25 \mathrm{~kg} / \mathrm{m}^{2}(p=0.000$; $\mathrm{OR}=9.33)$. Also, each unit increase in BMI increases the risk of fatty liver 1.48 -fold $(p<0.001 ; \mathrm{OR}=1.48)$ and eventually leads to CIMT. The risk of hypertension among men aged 20-50 years old was 2.86 times greater than for females in the same age range $(p=0.045$; $\mathrm{OR}=2.86)$. Male gender also is directly associated with an increase in the risk of fatty liver (independent of hypertension) $(p=0.022$; $\mathrm{OR}=3.025)$.

The risk of hypertension in smokers versus nonsmokers was $8.49(p=0.002$; OR $=8.49)$.

In addition to the aforementioned factors (including age, hypertension, diabetes, obesity, gender, and smoking) in the casual course, in dyslipidaemic patients with CIMT, aged 20 to 50 years, the risk increased directly or through an increase in the fatty liver risk; furthermore, nonalcoholic fatty liver alone or directly is linked to an increase in the mean CIMT and maximum CIMT with dyslipidaemia.

The presence of NAFLD grades II and III was associated with a $0.06 \mathrm{~mm}$ increase in mean CIMT $(p=0.015)$ and a $0.03 \mathrm{~mm}$ increase in the maximum CIMT in 20-50-year-old patients with dyslipidaemia $(p=0.001)$. Plaques in the carotid arteries were presented in 4 patients ( 2 patients in the case and 2 patients in the control groups), in which significant stenosis was not observed in any of the cases. No significant differences were observed between groups in the incidence of carotid artery plaque during the study.

\section{Discussion}

Based on the results obtained in this study, the mean maximum CIMT in patients with NAFLD was significantly more than the control group. So far, several studies were conducted on NAFLD and its rela- tionship with atherosclerosis and the carotid artery in general or in association with risk factors such as diabetes, and different results were also obtained, but, to the best of our knowledge, there is no study in which dyslipidaemia has been considered.

Moreover, the multifactorial nature of NAFLD and atherosclerosis would lead to costly and time-consuming research, which seems to be the reason for the lack of implementation of such research in Iran.

Since atherosclerosis of peripheral vessels such as carotid and late diagnosis increases the risk of cardiovascular and cerebrovascular adverse events, and is associated with mortality and morbidity, in this study we attempted to assess the role of ultrasound of the liver as a non-invasive technique on the basis of evidence in patients with dyslipidaemia, who are at risk of NAFLD, and its relation with peripheral vascular atherosclerosis. The results may suggest a liver ultrasound scan to assess the patients with dyslipidaemia for the presence of NAFLD as a sign of early carotid atherosclerosis.

Thus, such a strategy helps the prognosis for patients with early detection and facilitates the treatment of early-stage atherosclerosis, as well as decreasing the risk of cardiovascular events in these patients.

Brea et al. [16] studied 40 patients with an ultrasound diagnosis of primary NAFLD and 40 matched population controls, and examined whether NAFLD was associated with atherosclerosis, as measured by ultrasound in the carotid arteries. They reported that patients with NAFLD had more carotid atherosclerosis than the control group, and the mean CIMT in the NAFLD group was about $0.7 \mathrm{~mm}$ vs. $0.54 \mathrm{~mm}$ in the control group. The plaque was also more prevalent in the NAFLD group. They claimed that NAFLD is a consequence of the metabolic syndrome, and its detection on ultrasound should alert to the presence of increased risk of cardiovascular events.

In addition, using ultrasonography, Targher et al. [17] measured CIMT in 85 consecutive patients with biopsy-proven NAFLD compared to 160 healthy controls and assessed the association of NAFLD with CIMT as a marker of subclinical atherosclerosis. They also investigated whether such an association is independent of classical risk factors and metabolic syndrome features. They reported that the NAFLD group had a significantly greater CIMT (1.14 vs. $0.82 \mathrm{~mm})$ than the control group. They suggested that the severity of liver disease among patients with NAFLD is strongly associated with early carotid atherosclerosis. Sookoian and Pirola [18] systematically reviewed the studies addressing the association between NAFLD and CIMT and found a significant association between them. They recommended a CIMT measurement in NAFLD patients, as they carry an increase in the risk of occurrence of CIMT. 
In the present study, the mean CIMT was $0.66 \mathrm{~mm}$ in the case group, which was significantly higher than in the control group ( $0.66 \mathrm{~mm}$ vs. $0.58 \mathrm{~mm}$ ); furthermore, the maximum mean of CIMT in the patient group also showed a significant difference with the maximum mean of CIMT in the control group. Our results are also matched with the results of similar studies in patients with nonalcoholic fatty liver disease.

Poanta et al. [19] evaluated 56 patients with uncomplicated type 2 diabetes by ultrasonography considering plasma liver function tests and other biochemical blood measurements such as dyslipidaemia. They suggested that NAFLD is not associated with CIMT and may be due to more complex mechanisms.

Compared to the patients without NAFLD, the increased CIMT in the patients with dyslipidaemia with NAFLD is considerable. Thus, liver ultrasound should be considered as a part of an initial assessment in people diagnosed with a form of dyslipidaemia, and in the case of NAFLD its symptoms, such as atherosclerotic changes, should be most observation in patients, particularly if an inexpensive and safe noninvasive imaging method such as ultrasound is available.

\section{Conclusions}

The presence of NAFLD grades II and III was associated with a $0.06 \mathrm{~mm}$ increased mean CIMT. However, we suggest that in the case of the variables such as smoking and diabetes, studies with a larger sample size are recommended, in which the risk of complications and their association might be studied more accurately. Moreover, more studies on over 50-year-old patients are recommended to evaluate the association of plaque with stenosis of the carotid artery.

\section{Conflict of interest}

The authors declare no conflict of interest.

\section{References}

1. Browning JD, Szczepaniak LS, Dobbins R, Nuremberg P, Horton JD, Cohen JC, Grundy SM, Hobbs HH. Prevalence of hepatic steatosis in an urban population in the United States: impact of ethnicity. Hepatology 2004; 40: $1387-$ 1395.

2. Palmieri VO, Grattagliano I, Portincasa P, Palasciano G. Systemic oxidative alterations are associated with visceraladiposity and liver steatosis in patients with metabolic syndrome. J Nutr 2006; 136: 3022-3026.

3. Petit JM, Guiu B, Terriat B, Loffroy R, Robin I, Petit V, Bouillet B, Brindisi MC, Duvillard L, Hillon P, Cercueil JP, Verges B. Nonalcoholic fatty liver is not associated with carotid intima-media thickness in type 2 diabetic patients. J Clin Endocrinol Metab 2009; 94: 4103-4106.

4. Garg A, Misra A. Hepatic steatosis, insulin resistance, and adipose tissue disorders. J Clin Endocrinol Metab 2002; 87: 3019-3022.
5. Ioannou GN, Weiss NS, Boyko EJ, Mozaffarian D, Lee SP. Elevated serum alanine aminotransferase activity and calculated risk of coronary heart disease in the United States. Hepatology 2006; 43: 1145-1151.

6. Ruttmann E, Brant LJ, Concin H, Diem G, Rapp K, Ulmer H. Gamma-glutamyltransferase as a risk factor for cardiovascular disease mortality: an epidemiological investigation in a cohort of 163,944 Austrian adults. Circulation 2005; 112: 2130-2137.

7. Assy N, Djibre A, Farah R, Grosovski M, Marmor A. Presence of coronary plaques in patients with nonalcoholic fatty liver disease. Radiology 2010; 254: 393-400.

8. Hamaguchi M, Kojima T, Takeda N, Nakagawa T, Taniguchi H, Fujii K, Omatsu T, Nakajima T, Sarui H, Shimazaki M, Kato T, Okuda J, Ida K. The metabolic syndrome as a predictor of nonalcoholic fatty liver disease. Ann Intern Med 2005; 143: 722-728.

9. Marchesini G, Brizi M, Bianchi G, Tomassetti S, Bugianesi E, Lenzi M, McCullough AJ, Natale S, Forlani G, Melchionda N. Nonalcoholic fatty liver disease: a feature of the metabolic syndrome. Diabetes 2001; 50: 1844-1850.

10. Ishizaka N, Ishizaka $Y$, Yamakado $M$, Toda E, Koike $K$, Nagai R. Association between metabolic syndrome and carotid atherosclerosis in individuals without diabetes based on the oral glucose tolerance test. Atherosclerosis 2009; 204: 619-623.

11. Charlton M, Sreekumar R, Rasmussen D, Lindor K, Nair KS. Apolipoprotein synthesis in nonalcoholic steatohepatitis. Hepatology 2002; 35: 898-904.

12. Saadeh S, Younossi ZM, Remer EM, Gramlich T, Ong JP, Hurley M, Mullen KD, Cooper JN, Sheridan MJ. The utility of radiological imaging in nonalcoholic fatty liver disease. Gastroenterology 2002; 123: 745-750.

13. Markus RA, Mack WJ, Azen SP, Hodis HN. Influence of lifestyle modification on atherosclerotic progression determined by ultrasonographic change in the common carotid intima-media thickness. Am J Clin Nutr 1997; 65: 1000-1004.

14. Niu L, Zhang Y, Qian M, Meng L, Xiao Y, Wang Y, Liu X, Zheng R, Zheng $\mathrm{H}$. Impact of multiple cardiovascular risk factors on carotid intima-media thickness and elasticity. PLoS One 2013; 8: e67809.

15. Poanta LI, Albu A, Fodor D. Association between fatty liver disease and carotid atherosclerosis in patients with uncomplicated type 2 diabetes mellitus. Med Ultrason 2011; 13: 215-219.

16. Brea A, Mosquera D, Martín E, Arizti A, Cordero JL, Ros E. Nonalcoholic fatty liver disease is associated with carotid atherosclerosis: a case-control study. Arterioscler Thromb Vasc Biol 2005; 25: 1045-1050.

17. Targher G, Bertolini L, Padovani R, Rodella S, Zoppini G, Zenari L, Cigolini M, Falezza G, Arcaro G. Relations between carotid artery wall thickness and liver histology in subjects with nonalcoholic fatty liver disease. Diabetes Care 2006; 29: 1325-1330.

18. Sookoian S, Pirola CJ. Non-alcoholic fatty liver disease is strongly associated with carotid atherosclerosis: a systematic review. J Hepatol 2008; 49: 600-607.

19. Poanta LI, Albu A, Fodor D. Association between fatty liver disease and carotid atherosclerosis in patients with uncomplicated type 2 diabetes mellitus. Med Ultrason 2011; 13: 215-219. 


\section{Address for correspondence:}

\section{Hamid Dehdashti Shahroukh}

Department of Radiology

Atherosclerosis Research Centre

Jundishapur University of Medical Sciences

Ahvaz, Iran

Phone: +98 6112226040

E-mail: medical.imaging97@gmail.com 